\author{
A.K. Ramazanov*, L.G. Babeshina \\ Scientific Center for Examination of Medical Devices of Ministry of Health of Russia, Moscow, Russia
}

\title{
Assessment of the effect of long-term seed storage on the viability of Matricaria chamomilla seeds after cryopreservation
}

\begin{abstract}
The article presents the study of influences of cryopreservation on seed germination of Matricaria chamomilla. Four varieties «Moscow Region», «Karagandinskaya», «Aibolit» and «Old Lekar» are used in the work. The seeds of the test species are cryopreserved in liquid nitrogen, followed by defrosting at room temperature and rapid defrosting in a water bath at temperature $+40{ }^{\circ} \mathrm{C}$. After cryopreservation the seeds are planted in Petri dishes and placed in a climate chamber for determination laboratory germination. It is noted that the best results are obtained in the defrosting variant at the room temperature. Therefore, the maximum germination rate for variety «Karagandinskaya» was $84.0 \%$, energy of germination $-83.0 \%$; for «Aibolit» variety was $82.0 \%$ and $81.0 \%$, respectively; «Moscow Region» variety had a minimum germination rate $13.0 \%$ and energy of germination $10.0 \%$. While for the «Old Lekar» variety, the optimal thawing mode was rapid thawing in a water bath at the temperature $+40^{\circ} \mathrm{C}$; seed germination was $63.0 \%$, energy of germination $-62.0 \%$. Thus, it is necessary for receiving more viable seeds of varieties of Matricaria chamomilla after freezing in liquid nitrogen to apply the slow mode of thawing at the room temperature $+24{ }^{\circ} \mathrm{C}$.
\end{abstract}

Keywords: Matricaria chamomilla, cryopreservation, laboratorial germination, energy of germination, seed material.

\section{Introduction}

At present times, the conservation of the gene pool as one of the tasks in the conservation of nature is given great attention worldwide. This is due to the limited biological resources necessary for human existence and the threat of their depletion caused by the powerful technological impact of civilization on the environment, which sometimes affects plants. Many plant species are not yet well studied, but they are all genetic resources that a human can use. Therefore, the loss of any of them is an irreparable problem [1].

During the process of introducing wild medicinal plants, optimization of the storage conditions of the seed material plays an important role, as long as possible. Seed storage is a set of measures aimed at preserving the sown and varietal qualities of the seed fund. To preserve seeds work is carried out based on physical and physiological properties of studied seed mass [2].

The most important indicator of seeds in organizing storage activities is ensuring viability (germination rate and energy of germination). During long-term storage the germination of many crops varies greatly. Freshly harvested seeds do not always have good germination. For many seeds additional time is needed so that they end the processes of post-harvest maturation. It is noted that the seeds of some plants retain germination for years, others for decades [3].

Traditional methods of storage at the low positive temperatures and in the cabinet freezer are not able to provide high-quality storage, which is associated with drying up of plant material, damage by fungal and bacterial infections and pests. Therefore, one of the modern directions of preservation of seeds of wild and cultivated medicinal plants is freezing in liquid nitrogen at the extra low temperatures $\left(-196{ }^{\circ} \mathrm{C}\right)[4,5]$.

Seeds are the most optimal form of storage of genetic material, since samples require relatively little care and remain viable for a long period of time [6]. To this purpose in early 1970s the first centers for the long-term preservation of germ plasm were organized in a number of countries (Italy, Germany, USA, Japan). Since the life expectancy of seeds is very different: from several hours (in some tropical orchids) to tens and hundreds of years, one of the most important issues is their storage regime, which depends on species belonging, anatomical, physiological, biochemical, morphological features of seeds, has well as the conditions of their storage (temperature, humidity, composition of the gas composition, etc.) [7].

Cryopreservation of seeds and their isolated fragments is important for ex situ preservation as a reserved repository. Also, this method of storing seeds is financially inexpensive and convenient, despite the fact that effective protocols are not developed for all plant species. At the moment many scientists are conducting research in the field of resistance of seeds to cryopreservation, their behavior during storage. The benefits of 
this direction related to cryopreservation can contribute to the management of seeds for reproduction and the conservation of their genetic resources [8-13]

In Central Kazakhstan the perspective species for cultivation and production of phytopreparations is Matricaria chamomilla. Chamomile (Chamomilla recutita (L.) Raushert., or Matricaria chamomilla L., M. recutita L.) is annual herbal plant of Asteraceae family [14-16]. Chamomile is in Pharmacopoeia in more, than twenty countries. This is a valuable medicinal plant, inflorescences containing essential oil, which includes more than 40 components, serve as raw materials. The main therapeutic properties are attributed to chamazulene; its content in breeding varieties can reach $10 \%$ or more.

Chamazulen has anti-inflammatory, sedative, anti-allergic and topically anesthetic properties, is able to activate the function of the immune system. Flavonoids, derivatives of apigenin, luteolin and quercetine, which have an anti-inflammatory effect, are found in the flowers of the chamomile. Beta-carotene, coumarins, sitosterol, antispasmodic glycoside, polysaccharides and organic acids are also found in raw materials $[15,17]$. Aromatic and pleasant taste of chamomile lets to use it in various food products, confectionery, alcoholic/soft drinks, sweets and jelly [17]. The main suppliers of chamomile raw materials to the world market are Argentina, Bulgaria, Germany, Egypt, Slovakia, Czech Republic. Ready dosage forms: Romazulan, Alor, Arfazetin, Rotokan, Camiloside [15, 18, 19].

The aim of present work is the assessment of influences of long-term storage of seeds on viability of varieties of Matricaria chamomilla after cryopreservation in liquid nitrogen.

\section{Materials and Methods}

The objects of the study were the seeds of Matricaria chamomilla of the four varieties «Karagandinskaya», «Aibolit», «Old Lekar» and «Moscow Region». Cryoprocessing was carried out by direct immersion of seeds in plastic tubes in Dewar vessels with liquid nitrogen $\left(-196{ }^{\circ} \mathrm{C}\right)$. The seed material is stored in a Dewar vessel for 6 months. Samples of seeds are defrosted at the room temperature (slow thawing $+24{ }^{\circ} \mathrm{C}$ ) and in a water bath $+40{ }^{\circ} \mathrm{C}$ (fast thawing). The viability of the seed material is evaluated by laboratory germination [20].

The control seed is stored in dry place in paper bags. Germination is calculated as the ratio of the number of germinated seeds to the number of planted and expressed as a percentage. After thawing, all seeds are set for germination in 50 pieces of Petri dishes in 4-fold repetition on two-layer filter paper, previously wetted with distilled water (Fig. 1).

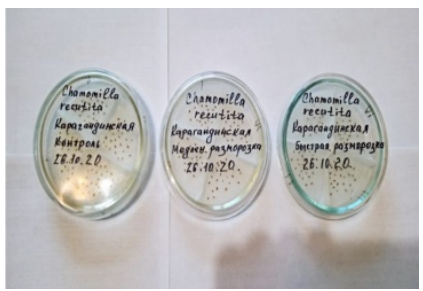

Karagandinskaya

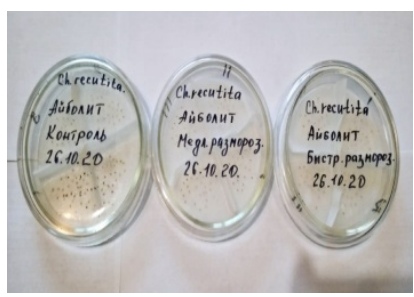

Aibolit

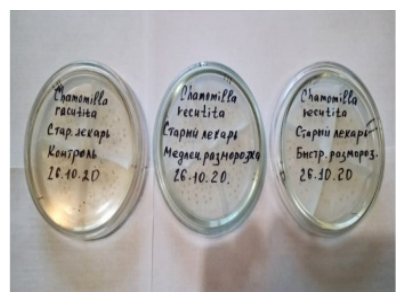

Old Lekar

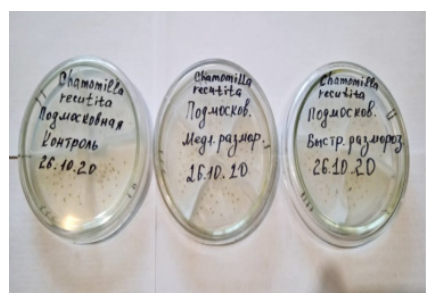

Moscow Region

Figure 1. Determination of viability of seeds of varieties of Matricaria chamomilla in the laboratorial conditions

Petri dishes with seed material are placed in climate chamber Binder at the temperature $+25^{\circ} \mathrm{C}$ with constant illumination.

\section{Results and Discussion}

Analysis of germination rate and energy of germination of the seed material of Matricaria chamomilla varieties after cryopreservation for 6 months according to the test versions with different defrosting types showed that the best results are noted in the version with defrosting at room temperature. Accodingly, the maximum germination rate for «Karagandinskaya» variety was $84.0 \%$, energy of germination was $83.0 \%$; for «Aibolit» variety was 82.0 and $81.0 \%$, respectively. «Moscow Region» variety had the minimum germination rate $13.0 \%$, energy of germination $10.0 \%$. Whereas for «Old Lekar» variety the optimal thawing mode was rapid thawing in a water bath $\left(+40^{\circ} \mathrm{C}\right)$, seed germination was $63.0 \%$, energy of germination was $62.0 \%$ (Tab. 1). 
Germination rate and energy of germination of seeds of Matricaria chamomilla varieties after 6 months cryopreservation

\begin{tabular}{|c|c|c|c|}
\hline Name of variety & Variant of experience & Germination rate, $\%$ & $\begin{array}{c}\text { Energy of germination, } \\
\%\end{array}$ \\
\hline \multirow{3}{*}{$\begin{array}{l}\text { «Karagandinskaya» } \\
\text { variety }\end{array}$} & Control & $90.0 \pm 1.5$ & $90.0 \pm 1.5$ \\
\hline & Cryopreservation with slow defrosting & $84.0 \pm 1.0$ & $83.0 \pm 0.8$ \\
\hline & Cryopreservation with fast defrosting & $41.0 \pm 1.4$ & $34.0 \pm 2.1$ \\
\hline \multirow{3}{*}{ «Aibolit» variety } & Control & $71.0 \pm 1.7$ & $70.0 \pm 1.5$ \\
\hline & Cryopreservation with slow defrosting & $82.0 \pm 1.6$ & $81.0 \pm 1.6$ \\
\hline & Cryopreservation with fast defrosting & $73.0 \pm 3.6$ & $70.0 \pm 4.9$ \\
\hline \multirow{3}{*}{ «Old Lekar» variety } & Control & $44.0 \pm 3.0$ & $40.0 \pm 3.6$ \\
\hline & Cryopreservation with slow defrosting & $41.0 \pm 0.8$ & $38.0 \pm 1.1$ \\
\hline & Cryopreservation with fast defrosting & $63.0 \pm 2.8$ & $62.0 \pm 3.0$ \\
\hline \multirow{3}{*}{$\begin{array}{l}\text { «Moscow Region» } \\
\text { variety }\end{array}$} & Control & $24.0 \pm 1.4$ & $18.0 \pm 0.8$ \\
\hline & Cryopreservation with slow defrosting & $13.0 \pm 1.9$ & $10.0 \pm 1.6$ \\
\hline & Cryopreservation with fast defrosting & $9.0 \pm 1.3$ & $6.0 \pm 0.5$ \\
\hline
\end{tabular}

After analyzing the obtained data, it is found that the seed material of «Karagandinskaya» variety showed maximum germination in the control group that amounted to $90.0 \%$, while the germination of seeds after cryopreservation with slow defrosting was $84.0 \%$, which is lower by $6.0 \%$ of the control samples. The minimum germination is demonstrated by seeds with rapid thawing: $41.0 \%$. Energy of germination depending on the test variant changed in the same way as germination rate. So, the control group was $90.0 \%$, while cryogenic storage with slow defrosting showed $83.0 \%$, with fast defrosting $-34.0 \%$ (Fig. 2).

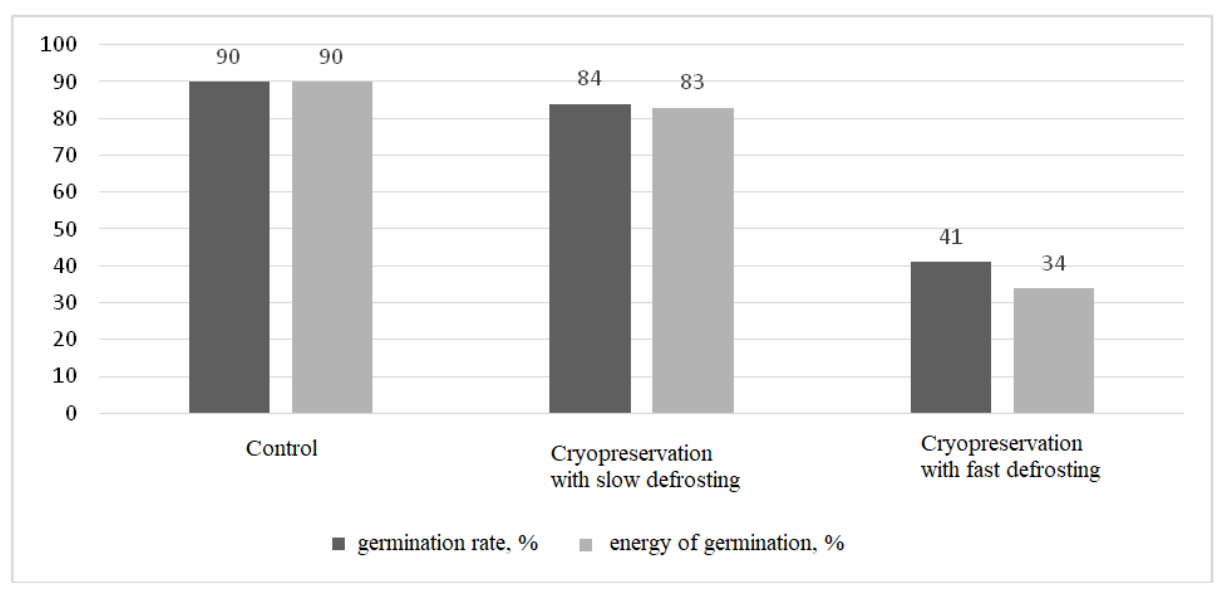

Figure 2. Determination of germination rate and energy of germination of seeds of Matricaria chamomilla, «Karagandinskaya» variety after long-term storage 6 months in liquid nitrogen

Different results are obtained for «Aibolit» variety. Compared to the control, the germination rate of seeds in the experimental group with slow defrosting and $2 \%$ with fast defrosting is increased by $11 \%$ ( $82.0 \%$ and $73.0 \%$, respectively). The control group showed the lowest germination - $71.0 \%$. Almost similar results were in the energy of germination: control - 70.0\%, cryopreservation with slow defrosting $81.0 \%$ and cryopreservation with fast defrosting - 70.0\% (Fig. 3). In this case extra-low temperatures had positive effect on the viability of the seeds of Matricaria chamomilla, «Aibolite» variety.

As follows from the data presented in Figure 4, cryopreservation had the best effect for «Old Lekar» variety during fast defrosting. So, the germination rate of seeds was $63.0 \%$, energy of germination $62.0 \%$. The minimum values of germination rate and energy of germination are shown by cryopreservation of seeds with slow defrosting - $41.0 \%$ and $38.0 \%$, respectively. Control values were also low. 


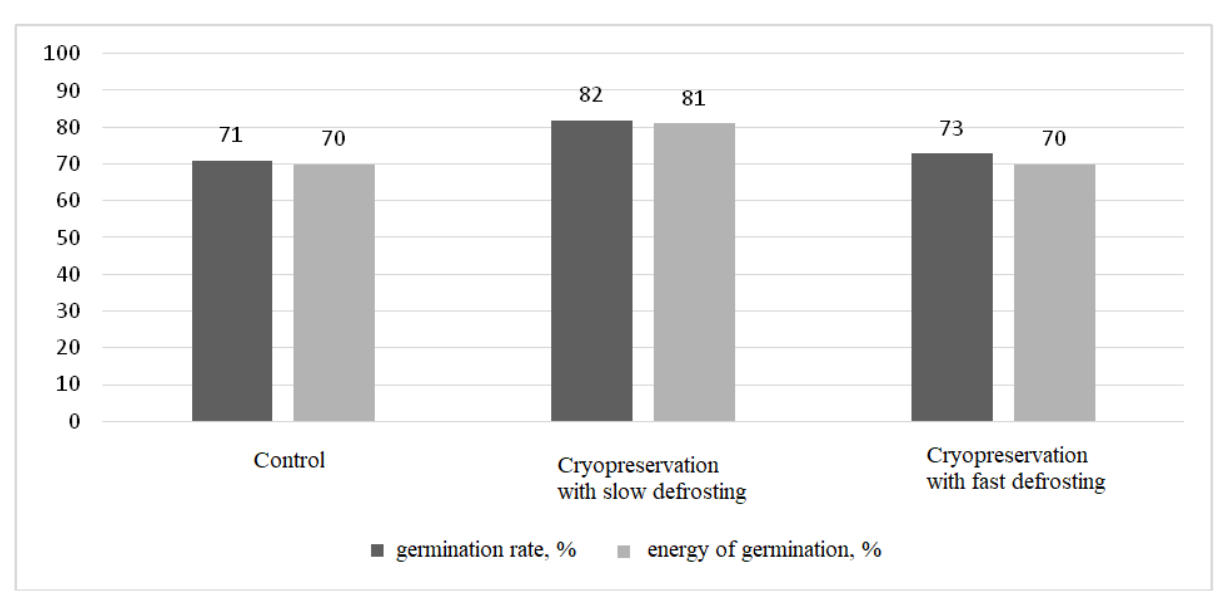

Figure 3. Determination of germination rate and energy of germination of seeds of Matricaria chamomilla, «Aibolit» variety after long-term storage 6 months in liquid nitrogen

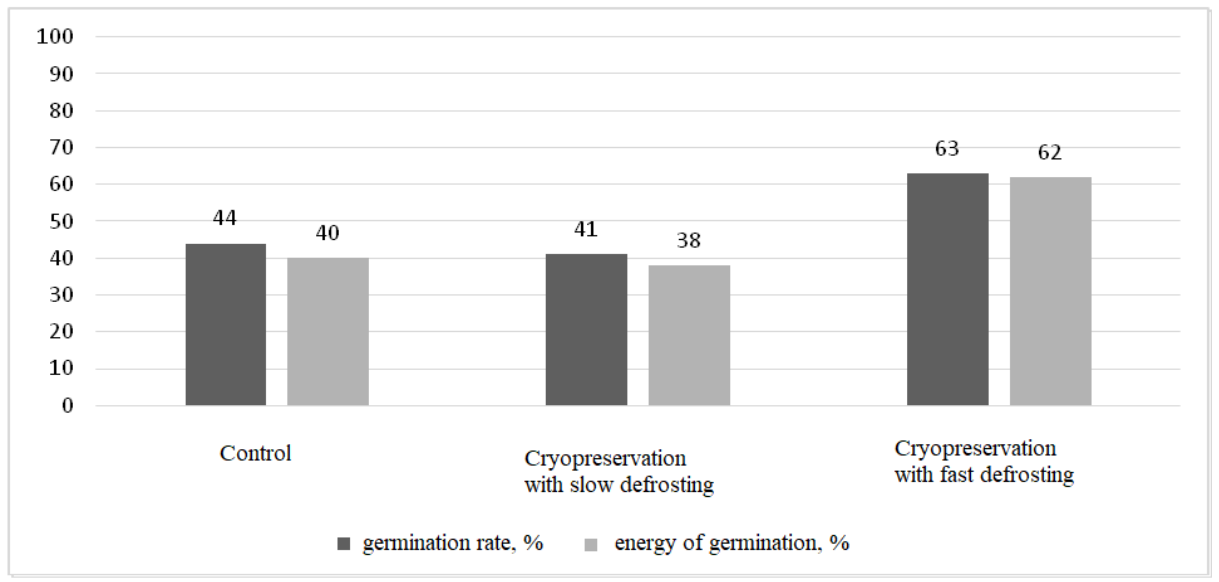

Figure 4. De termination of germination rate and energy of germination of seeds of Matricaria chamomilla, «Old Lekar» variety after long-term storage 6 months in liquid nitrogen

For «Moscow Region» variety, the viability of seeds, both in control and in experimental groups, turned out to be the lowest compared to the three previous varieties (Fig. 5). Perhaps, this is due to the fact that seeds of this variety were stored for more than one year before cryopreservation.

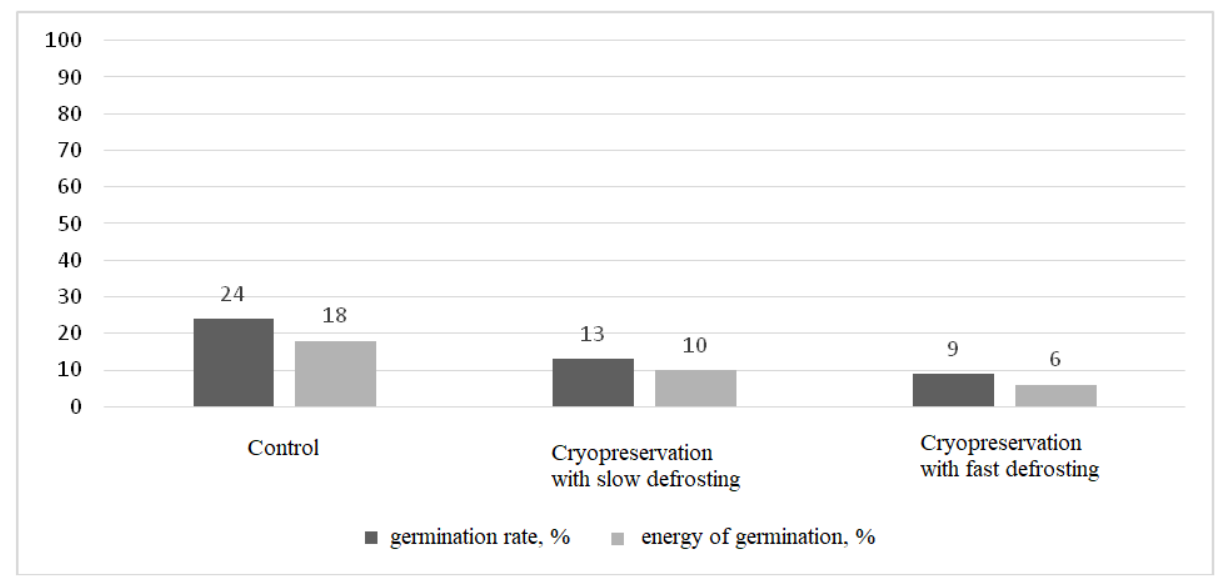

Figure 5. Determination of germination rate and energy of germination of seeds of Matricaria chamomilla, «Moscow Region» variety after long-term storage 6 months in liquid nitrogen 
According to literary data, the maximum germination rate is noted for chamomile seeds storage 6-12 months, after which a gradual decrease in germination rate is observed [21]. Also, a number of authors [22] established important facts revealing some reasons for the low germination of seeds in plants by their storage: a decrease in breathing intensity, increasing free fatty acid content, reducing the content of vital substances; reducing sucrose content, action of pathogenic microflora. The cryopreservation of seeds in this case did not have any positive effect. Germination rate and energy of germination of the control group seeds were 24.0 and $18.0 \%$, cryopreservation with slow thawing - 13.0 and $10.0 \%$, cryopreservation with fast defrosting $-9.0 \%$ and $6.0 \%$.

\section{Conclusion}

Thus, in order to obtain more viable seeds of chamomile varieties, when freezing in liquid nitrogen, a slow thawing regime should be used at room temperature $+24^{\circ} \mathrm{C}$; for long-term storage purposes the seed material should be cryopreserved using cryoprotective substances, since in some experimental groups the germination and germination energy of seeds were still lower than control values.

\section{References}

1 Жумагулова Ж.Б. Совершенствование биотехнологических методов сохранения генофонда груши: дис. ... д-ра филос. (PhD) / Ж.Ж. Жумагулова. - Алматы, 2014. — 87 с.

2 Тоцкая С.А. Особенности технологии возделывания ромашки аптечной (Matricaria chamomilla L.) на семена С.А. Тоцкая, Н.Т. Конан // Изв. ТСХА. - 2010. - Вып. 2. - С. 91-98.

3 Бессонова Л.В. Влияние сроков посева и норм высева на урожайность и технологические качества пивоваренных сортов ячменя в Предуралье / Л.В. Бессонова // Проблемы сельскохозяйственного производства в изменяющихся экономических и экологических условиях: материалы Междунар. науч.-практ. конф. - Смоленск, 1999. — С. $144,145$.

4 Reed B.M. The basics of in vitro storage and cryopreservation. - Corvallis: National Clonal Germplasm Repository, 2002. - P. 34-46.

5 Криохранение семян: итоги и перспективы. - Новосибирск: Изд-во СО РАН, 2014. — 110 с.

6 Свистунова Н.Ю. Изучение влияния продолжительности и режима хранения сортовых семян лекарственных растений на основные посевные качества и цитогенетические характеристики их проростков / Н.Ю. Свистунова // Роль ботанических садов и дендрариев в сохранении, изучении и устойчивом использовании разнообразия растительного мира: материалы Междунар. науч. конф. - Минск, 2017. - С. 528.

7 Бутенко О.Ю. Влияние режимов замораживания и оттаивания на всхожесть семян сосны и ели / О.Ю. Бутенко, А.С. Бондаренко, Н.Н. Пелевина // Тр. СПб. науч.-исслед. ин-та лесного хозяйства. — 2014. — № 1. — С. 38-46.

8 Rodrigo A.D. Storage, oil quality and cryopreservation of babassu palm seeds / A.D. Rodrigo, C. Silma, A.O. Neves, M.R. Leonardo, S. N.L. Paulo, O.S. Flaviano // Industrial Crops and Products. - 2016. -Vol. 91. - P. 332-339.

9 Sisunandar P.A.S. Dehydration improves cryopreservation of coconut (Cocos nucufera L.) / P.A.S. Sisunandar, Y. Samosir, A. Rival, S.W. Adkins // Cryobiology. — 2010. - Vol. 61. - P. 289-296.

10 Engelmann F. Plant cryopreservation: progress and prospects / F. Engelmann // In Vitro Cell. Dev. Biol. Plant. — 2004. Vol. 40. - P. 427-433.

11 Wen B. Pretreatment incubation for culture and cryopreservation of Sabal embryos / B. Web, R. Wang // Plant Cell Tiss. Org. - 2010. - Vol. 102. - P. 237-243.

12 Dias D.S. Tolerance of desiccation and cryopreservation of Butia capitata palm seeds / D.S. Dias, P. S.N. Lopes, L.M. Ribeiro, L. A.A. Oliveira, E.V. Mendes, V.S. Carvalho // Seed Sci. Technol. - 2015. — Vol. 43. P. 90-100.

13 Ngobese N. Cryopreservation of the embryonic axes of Phoenix reclinata, a representative of the intermediate seeds category / N. Ngobese, Z. Sershen, N.W. Pammenter, P. Berjak // Seed Sci. and Technol. - 2010. — Vol. 38. - P. 704-716.

14 Атлас лекарственных растений России. - М., 2006. - 350 с.

15 Тоцкая C.A. Ромашка аптечная (Chamomilla recutita (L.) Raushert.) - объект селекции / C.А. Тоцкая, М.Ю. Грязнов // Биологические особенности лекарственных и ароматических растений и их роль в медицине: сб. науч. тр. Междунар. науч.практ. конф. - М., 2016. - С. 321-324.

16 Nektaria T. Phenotypic variation of wild Chamomile (Matricaria chamomilla L.) populations and their evaluation for medicinally important essential oil / T. Nektaria, S. Eirini, G. Katerina, P. Chrysanthi, K. Theodoros, Ch. Paschalina, M. Athanasios // Biochemical Systematic and Ecology. — 2018. — Vol. 80. — P. 21-28.

17 Aleksandra C. Subcritical water extraction as a cutting edge technology for the extraction of bioactive compounds from chamomile: Influence of pressure on chemical composition and bioactivity of extracts / C. Aleksandra, S. -G. Jaroslava, Z. Zoran, G. Uros, T. Zivoslav, Z. Gokhan, M. Pavle, F.M. Mohamad, D. Sasa // Food Chemistry. — 2018. — Vol. 266. — P. 389-396.

18 Фитопрепараты ВИЛАР: науч.-справоч. изд. - М.: Борус-пресс, 2009. — 256 с.

19 Регистр лекарственных средств России. - М.: Веданта, 2015. - 351 с.

20 Зорина М.С. Определение семенной продуктивности и качества семян интродуцентов / М.С. Зорина, С.П. Кабанов // Методики интродукционных исследований в Казахстане. - Алма-Ата: Наука, 1986. - С. $75-85$. 
21 Тлеукенова С.У. Онтогенез ромашки аптечной сорта «Карагандинская» в условиях Центрального Казахстана

/ С.У. Тлеукенова, С.С. Айдосова, М.Ю. Ишмуратова // Вестн. Казах. нац. ун-та. Сер. биол. — 2008. — № 3. — С. 13-15.

22 Губанов И.А. Лекарственные растения / И.А. Губанов. - М.: Московские университеты, 1993. — С. 8.

А.К. Рамазанов, Л.Г. Бабешина

\title{
Криоконсервациядан кейін Matricaria chamomilla сорты тұқымының өміршендігінің ұзақ мерзімді тұқым сақтау әсерінің бағалауы
}

\begin{abstract}
Мақалада криоконсервацияның түймедақ тұқымдарының өнуіне әсері зерттелген. Авторлар «Подмосковная», «Карагандинская», «Айболит» және «Старый лекарь» деген төрт сортты қолданған. Зерттелген түрлердің тұқымдары сұйық азотта криоконсервацияланған, содан кейін бөлме температурасында және $+40^{\circ} \mathrm{C}$ су моншасында тез еруіне ұшыраған. Криоконсервациядан кейін тұқымдар Петри табақшаларына отырғызылып, зертханалық өнгіштікті анықтау үшін климаттық камераға орналастырылды. Ең жақсы нәтиже бөлме температурасында еріту арқылы алынғандығы белгіленді. Сонымен, тұқымның максималды өнгіштігі «Карагандинская» сорты үшін 84,0 \%, өну энергиясы 83,0 \% «Айболит» сорты үшін сәйкесінше 82,0 \% және 81,0 \% құрады. «Подмосковная» сортының өну минимумы 13,0 \% және өну энергиясы 10,0 \%. «Старый лекарь» сорты үшін оңтайлы еріту режимі $+40^{\circ} \mathrm{C}$ су моншасында тез жібіту болды, тұқым өнгіштігі 63,0 \%, өну энергиясы 62,0 \%. Осылайша, түймедақ сорттарының өміршең тұқымдарын алу үшін сұйық азотта мұздағанда бөлме температурасында $+24^{\circ} \mathrm{C}$ баяу еріту режимін қолдану қажет.
\end{abstract}

Кілm сөздер: Matricaria chamomilla, криоконсервация, зертханалық өнгіштік, өну энергиясы, тұқымдық материал.

\author{
А.К. Рамазанов, Л.Г. Бабешина
}

\section{Оценка влияния долгосрочного хранения семян на жизнеспособность семян сортов Matricaria chamomilla после криоконсервации}

\begin{abstract}
В статье изучено влияние криоконсервации на всхожесть семян ромашки аптечной. Авторами были использованы четыре сорта «Подмосковная», «Карагандинская», «Айболит» и «Старый лекарь». Семена исследуемых видов подвергались криоконсервации в жидком азоте с последующим размораживанием при комнатной температуре и быстрым размораживанием на водяной бане при $+40^{\circ} \mathrm{C}$. После криоконсервации семена высаживали в чашках Петри и помещали в климатическую камеру для определения лабораторной всхожести. Было отмечено, что наилучшие результаты получены в варианте с размораживанием при комнатной температуре. Так, максимальная всхожесть семян для сорта «Карагандинская» составила 84,0 \%, энергия прорастания 83,0 \%, для сорта «Айболит» - 82,0\% и 81,0\%, соответственно, у сорта «Подмосковная» отмечена минимальная всхожесть 13,0 \% и энергия прорастания 10,0 \%. Тогда как для сорта «Старый лекарь» оптимальным режимом оттаивания являлось быстрое размораживание на водяной бане при $+40^{\circ} \mathrm{C}$, всхожесть семян составила 63,0 \%, энергия прорастания $62,0 \%$. Таким образом, для получения более жизнеспособных семян сортов ромашки аптечной необходимо при замораживании в жидком азоте применять медленный режим оттаивания при комнатной температуре $+24^{\circ} \mathrm{C}$.
\end{abstract}

Ключевые слова: Matricaria chamomilla, криоконсервация, лабораторная всхожесть, энергия прорастания, семенной материал.

\section{References}

1 Zhumagulova, Zh.B. (2014). Sovershenstvovanie biotekhnologicheskikh metodov sokhraneniia genofonda grushi [Improving biotechnological methods for preserving the pear gene pool]. Doctor's thesis. Almaty [in Russian].

2 Totskaia, S.A., \& Konon, N.T. (2010). Osobennosti tekhnologii vozdelyvaniia romashki aptechnoi (Matricaria chamomilla L.) na semena [Features of the technology of cultivation of chamomile (Matricaria chamomilla L.) for seeds]. Izvestiia TSKHA - Bulletin of TAGA, 2, 91-98 [in Russian].

3 Bessonova, L.V. (1999). Vliianie srokov poseva i norm vyseva na urozhainost i tekhnologicheskie kachestva pivovarennykh sortov yachmenia $v$ Predurale [Influence of sowing dates and seeding rates on the yield and technological qualities of brewing barley varieties in the Urals]. Problems of agricultural production in changing economic and environmental conditions: materials of the international scientific-practical conference. Smolensk [in Russian].

4 Reed, B.M. (2002). The basics of in vitro storage and cryopreservation. Corvallis: National Clonal Germplasm Repository. 
5 (2014). Kriokhranenie semian: itogi i perspektivy [Cryostorage of seeds: results and prospects]. Novosibirsk: Izdatelstvo SO RAN [in Russian].

6 Svistunova, N.Yu. (2017). Izuchenie vliianiia prodolzhitelnosti i rezhima khraneniia sortovykh semian lekarstvennykh rastenii na osnovnye posevnye kachestva i tsitogeneticheskie kharakteristiki ikh prorostkov [Study of the influence of the duration and storage regime of varietal seeds of medicinal plants on the main sowing qualities and cytogenetic characteristics of their seedlings]. Materials of the International Scientific Conference dedicated to the 85th anniversary of the Central Botanical Garden of the National Academy of Sciences of Belarus: The role of botanical gardens and arboretums in the conservation, study and sustainable use of flora diversity. Minsk [in Russian].

7 Butenko, O. Yu., Bondarenko, A.S. \& Pelevina, N.N. (2014). Vliianie rezhimov zamorazhivaniia i ottaivaniia na vskhozhest semian sosny i eli [Influence of freezing and thawing regimes on the germination of pine and spruce seeds]. Trudy SanktPeterburgskogo nauchno-issledovatelskogo instituta lesnogo khoziaistva - Proceedings of the St. Petersburg Scientific Research Institute of Forestry, 1; 38-46 [in Russian].

8 Rodrigo, A.D., Silma, C., Neves, A.O., Leonardo, M.R., Paulo, S.N.L. \& Flaviano, O.S. (2016). Storage, oil quality and cryopreservation of babassu palm seeds. Industrial Crops and Products, 91; 332-339.

9 Sisunandar, P.A.S., Samosir, Y., Rival, A. \& Adkins, S.W. (2010). Dehydration improves cryopreservation of coconut (Cocos nucufera L.). Cryobiology, 61; 289-296.

10 Engelmann, F. (2004). Plant cryopreservation: progress and prospects. In Vitro Cell. Dev. Biol. Plant, 40; $427-433$.

11 Wen, B. \& Wang, R. (2010). Pretreatment incubation for culture and cryopreservation of Sabal embryos. Plant Cell Tiss. Org., 102; 237-243.

12 Dias, D.S., Lopes, P.S.N., Ribeiro, L.M., Oliveira, L.A.A., Mendes, E.V. \& Carvalho, V.S. (2015). Tolerance of desiccation and cryopreservation of Butia capitata palm seeds. Seed Sci. Technol., 43; 90-100.

13 Ngobese, N., Sershen, Z., Pammenter, N.W. \& Berjak, P. (2010). Cryopreservation of the embryonic axes of Phoenix reclinata, a representative of the intermediate seeds category. Seed Sci. and Technol., 38; 704-716.

14 Bykova, V.A. (2006). Atlas lekarstvennykh rastenii Rossii [Atlas of medicinal herbs of Russia]. Moscow [in Russian].

15 Totskaia, S.A. \& Griaznov, M.Iu. (2016). Romashka aptechnaia (Chamomilla recutita (L.) Raushert.) — obekt selektsii [Pharmacy chamomile (Chamomilla recutita (L.) Raushert.) — an object of selection]. Collection of scientific papers of the International Scientific and Practical Conference dedicated to the 85th anniversary of VILAR: Biological characteristics of medicinal and aromatic herbs and their role in medicine. Moscow [in Russian].

16 Nektaria, T., Eirini, S., Katerina, G., Chrysanthi, P., Theodoros, K., Paschalina, Ch. \& et al. (2018). Phenotypic variation of wild Chamomile (Matricaria chamomilla L.) populations and their evaluation for medicinally important essential oil. Biochemical Systematic and Ecology, 80; 21-28.

17 Aleksandra, C., Jaroslava, S. -G., Zoran, Z., Uros, G., Zivoslav, T., Gokhan, Z. \& et al. (2018). Subcritical water extraction as a cutting edge technology for the extraction of bioactive compounds from chamomile: Influence of pressure on chemical composition and bioactivity of extracts. Food Chemistry, 266; 389-396.

18 (2009). Fitopreparaty VILAR: nauchno-spravochnoe izdanie [Phytopreparations VILAR: a scientific reference publication]. Moscow: Borus-press [in Russian].

19 (2015). Registr lekarstvennykh sredstv Rossii [Register of medical facilities of Russia]. Moscow: Vedanta [in Russian].

20 Zorina, M.S. \& Kabanov, S.P. (1986). Opredelenie semennoi produktivnosti i kachestva semian introdutsentov [Determination of seed productivity and quality of seeds of introduced plants]. Metodiki introduktsionnykh issledovanii v Kazakhstane Methodology of introduced study in Kazakhstan. Alma-Ata: Nauka [in Russian].

21 Tleukenova, S.U., Aidosova, S.S. \& Ishmuratova, M.Yu. (2008). Ontogenez romashki aptechnoi sorta «Karagandinskaia» v usloviiakh Tsentralnogo Kazakhstana [Ontogenesis of Chamomilla reticuta sort «Karagandinskaya» in the conditions of the Central Kazakhstan]. Vestnik Kazakhskogo natsianalnogo universiteta. Seriia biologiia - Bulletin of KazNU, biology series, 3, 13-15 [in Russian].

22 Gubanov, I.A. (1993). Lekarstvennye rasteniia [Medicinal herbs]. Moscow: Moskovskie universitety [in Russian]. 